Dept. of Food Hygiene

Fac. of Vet. Med., Assiut University, Assiut, Egypt.

\title{
BACTERIAL-FLORA OF EGYPTIAN SALTED MUGIL CEPHALUS FISH (FESSIEKH) PCR - IDENTIFICATION
}

(With 4 Tables and One Picture)

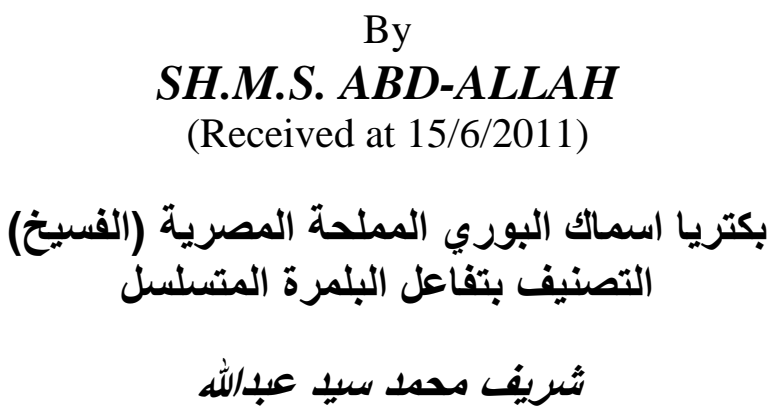

أجريت هذه الدراسة على 17 عينة من اسماك البوري المملحة المصرية (الفسيخ) حيث تم

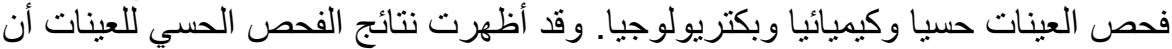

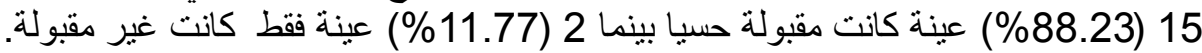

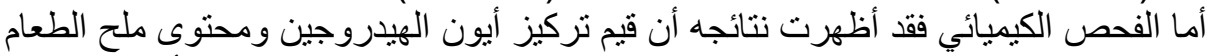

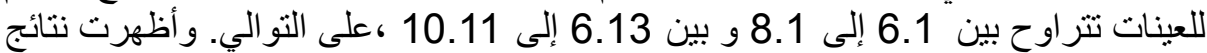

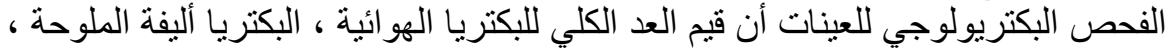

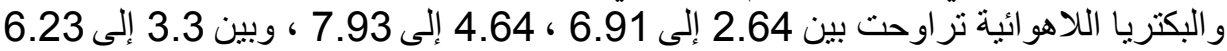

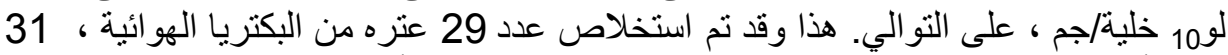

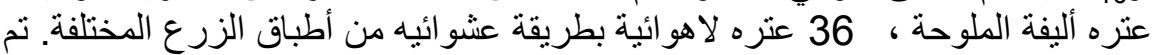

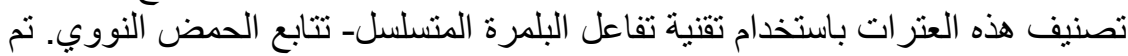

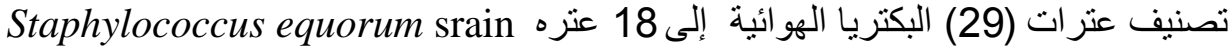

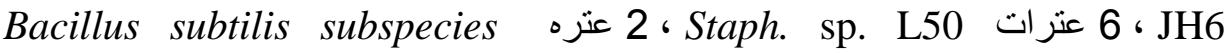
Lactobacillus sp. CWBI/B- 2 ، subtilis strain BCRC 10255 659/(E912) 1 و عترة Bacillus subtilis ، وتم تصنيف ال 31 ، 31 عتره من البكتريا أليفة

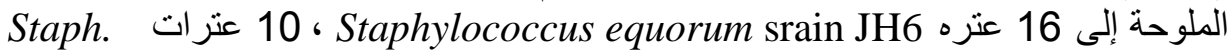

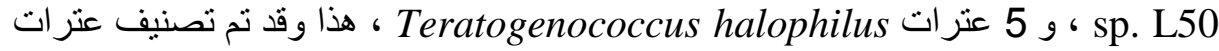

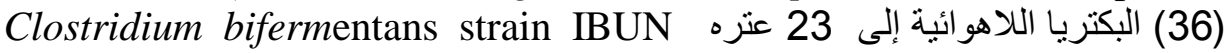
188 ، 7 عتر ات Clostridium bifermentans strain IBUN 179

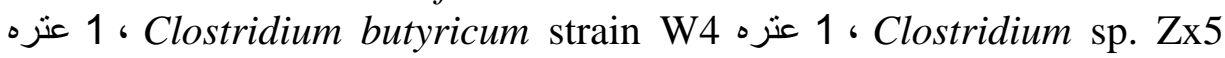
Clostridium sp. DF2C1 Clostridium cochlearium 
A total of 17 samples of Egyptian salted Mugil cephalus fish (fessiekh) were examined sensorial for appearance, juiciness, saltiness, rancidity, flavor and general acceptability; chemically for $\mathrm{pH}$ and $\mathrm{NaCl}$ content; and bacteriologically for aerobic plate count, halophilic bacterial count and anaerobic bacterial count. The sensory evaluation of the samples revealed that $15(88.23 \%)$ of them were organoleptically accepted, while only $2(11.77 \%)$ were unaccepted. The $\mathrm{pH}$ and $\mathrm{NaCl}$ content of the examined samples ranged from 6.1 to 8.1 and from 6.13 to 10.11, respectively. The aerobic, halophilic and anaerobic bacterial counts of the examined samples ranged from 2.64 to $6.91,4.64$ to 7.93 , and from 3.3 to $6.23 \log _{10} \mathrm{cfu} / \mathrm{g}$, respectively. A total of 29,31 and 36 colonies were picked randomly from aerobic, halophilic and anaerobic plates, respectively. The colonies were purified and being identified using PCRsequencing technique. The 29 identified aerobic bacteria were 18 strains Staphylococcus equorum srain JH6, 6 strains Staph. sp. L50, 2 strain Bacillus subtilis subspecies subtilis strain BCRC 10255, 2 strains Lactobacillus sp. CWBI/B-659/(E912), and 1 strains Bacillus subtilis. The identified 31 halophilic bacteria included 16 strains Staphylococcus equorum srain JH6, 10 strains Staph. sp. L50, and 5 strains Teratogenococcus halophilus. The 36 identified anaerobes were Clostridium bifermentans strain IBUN 188 (23 strains), Clostridium bifermentans strain IBUN 179 (7 strains), Clostridium sp. Zx5 (3 strains), Clostridium butyricum strain W4 (1 strain), Clostridium cochlearium (1 strain), and Clostridium sp. DF2C1 (1 strain).

Key words: Salted fish, fesseikh, assessment, sensory, chemical, bacterial-flora, PCR-Identification.

\section{INTRODUCTION}

The salting process is one of oldest methods in preservation of fish, and this process has still been used in many places in the world, either for economic reasons, owing to its low production costs, or in order to satisfy consumer habits (Yang et al., 1981; Wheaton and Lawson, 1985). The effect of salt are obstructed growth of the microorganism or they destroyed, and in this way the fish meat gets durability (Tarr, 1969; Filsinger, 1987).

Historically, fish fermentation has been associated with the treatment of fish with salt and allowing the product to mature over several months (Kemp, 1973; Filsinger et al., 1982). The final product 
has a characteristic combination of appearance, odor, flavor and texture. The salting process is highly manipulative and with high potential for environmental transfer of microorganisms to the product. In addition some industrial abuses can occur, one of them being an excess of impurities in salt used for salting, e.g. $\mathrm{CaCl}_{2}$ and $\mathrm{MgCl}_{2}$ which retard the penetration of $\mathrm{NaCl}$, enhancing fish bacterial spoilage (Van Klaveren and Legendre, 1965).

In Egypt 'Fesiekh' is the Arabic name for a salted fermented Bouri (Mugil cephalus) fish. It is quite a popular food product, especially during certain occasions. Fessiekh is not a product of modern times considering its processing chain. Whole non-eviscerated fish are washed with tap water, and left to decompose for a day before salting. The salting process varies depending on the processor and so does the quality of the finished product; in general it involves stuffing of the gills and covering of the entire fish with approximately $15-25 \%$ salt by weight (El-Sebaiy and Metwalli, 1989). The process is done by unscientific methods with poor quality salt and unhygienic conditions.

As fessiekh constitute an important part of the diet of great portion of consumers in Egypt; and have been subjected to many risks of contamination from various sources (El-Sebaey et al., 1999), so it is very important to evaluate the hygienic quality of such fish product.

Determination of bacterial-flora of Fessiekh using culture methods has been reported (Morshdy et al., 1982; Abd-Allah 2008). Due to the known limitations of cultivation methods many recent studies have used culture independent 16S rRNA-based PCR techniques (Singh et al., 2009) including PCR-Denaturing Gradient Gel Electrophoresis (DGGE) and PCR-Single Strand Conformation Polymorphism (PCRSSCP) to determine the microflora of various traditional fermented Foods. (Chamkha et al., 2008; Chen et al., 2008; Kim et al., 2009).

In general, the identification of bacteria based on phenotypic analysis needs special knowledge and judgment is often subjective. It is considered that the evolutionary history of bacteria is memorized in their ribosomal RNAs, so that the systematic classification and identification of bacteria in recent years have been based on the analysis of rRNAs sequences (JPF, 2003).

The objective of this study was to determine the sensory; $\mathrm{pH}$ and sodium chloride content; as well as bacterial-flora of the Egyptian salted fish Mugil cephalus (fessiekh) and identifying the bacterial-flora isolates 
using a molecular approach, based on PCR amplification of divergent regions of the $16 \mathrm{~S}$ rRNA gene followed by sequencing and comparison of the sequences with those in the database (PCR-sequencing technique) for accurate definition of these flora.

\section{MATERIALS and METHODS}

In this study Egyptian salted Mugil cephalus fish (fessiekh) were used. The samples were obtained from the different salted-fish markets in Cairo - Egypt and totally 17 samples were collected. The samples were placed in sterile polyethylene bags and stored at $4 \pm 1^{\circ} \mathrm{C}$ until they were analysed.

\subsection{Sensory assessment}

Three consumer-based sensory panels were conducted to evaluate the appearance, juiciness, saltiness, rancidity, flavor and general acceptability of the examined salted fish samples (fessiekh) using a 5-point Hedonic Scale according to Ikeme (1986).

\section{2 chemical analysis}

The $\mathrm{pH}$ values of samples were determined by using a $\mathrm{pH}$ meter (IQ 120) at $25 \pm 1{ }^{\circ} \mathrm{C}$ (Lyhs et al., 1998). The salt content of the samples was determined according to the method described by AOAC (1980).

\subsection{Microbiological Analysis}

Decimal dilutions (up to $10^{6}$ ) of fish samples were prepared using sterile $0.1 \%$ peptone water solution. The appropriate dilutions were surface plated on appropriate media for enumeration of bacteria according to APHA (1984). The microbiological media and incubation conditions used for enumeration of microorganisms were Plate Count agar (PCA) for mesophilic aerobic microorganisms, (at $35 \pm 1{ }^{\circ} \mathrm{C}, 48$ hours) (APHA, 1984). The count of halophilic bacteria was determined on plate count agar with added $6 \%$ (w/v) $\mathrm{NaCl}\left(35 \pm 1{ }^{\circ} \mathrm{C}, 48\right.$ hours) (APHA, 1984). Gifu anaerobic medium (GAM agar, Nissui Co., Tokyo, Japan) was used to determine the anaerobic bacterial count $\left(35 \pm 1^{\circ} \mathrm{C}, 72\right.$ hours under anaerobic condition). The composition of the GAM medium was as follows $(\mathrm{gm} / \mathrm{L})$ : peptone, 10; soy bean peptone, 3; proteose peptone, 10; serum powder, 13.5; yeast extract, 5; beef extract powder, 2.2; liver extract powder, 1.2; glucose, $3, \mathrm{KH}_{2} \mathrm{PO}_{4}, 2.5 ; \mathrm{NaCl}, 3$; soluble starch, 5; L-cystine hydrochloride, 0.3; sodium thioglycolate, 0.3; agar, 15. 


\subsection{Purification and characterization of the bacterial isolates 2.4.1. Isolates purification}

Random number of colonies was selected from growing plates according to their phenotypic differences (color, size and shape). For purification each colony was subculture onto the surface of LuriaBertani (LB) agar plates (Sambrook and Russell, 2001) and incubated at appropriate conditions $\left(35 \pm 1^{\circ} \mathrm{C}, 24\right.$ hours). The media composition is as follow $(\mathrm{gm} / \mathrm{L})$ : bacteriological tryptone, 10; bacteriological yeast extract, 5; NaCl, 10; agar, 15. A separate and well isolated colony were picked up, inoculated into $5 \mathrm{ml} \mathrm{LB}$ broth (bacteriological tryptone, 10; bacteriological yeast extract, $5 ; \mathrm{NaCl}, 10 ; \mathrm{DW}, 1 \mathrm{~L})$ and incubated in shaking incubator $(100 \mathrm{rpm})$ at $35 \pm 1{ }^{\circ} \mathrm{C}$, for 24 hours. Either purified colonies on LB agar or in broth culture can be used to prepare templateDNA. For anaerobes, separate colonies was picked directly from GAM agar and used fro preparation of template-DNA.

\subsubsection{Template-DNA preparation}

Either colonies or its broth culture were used to prepare the template-DNA using heating in DNA-releasing solution at $100^{\circ} \mathrm{C}$ for 10 min according to JPF (2003).

\subsubsection{PCR running}

The used PCR primers were: $10 \mathrm{~F}$ (sense primer) 5GTTTGATCCTGGCTCA-3' and 800R (anti-sense primer) 5'TACCAGGGTATCTAATCC-3' (JPF, 2003). The PCR mixture per sample was as follow: 10X buffer, $5.0 \mu \mathrm{l}$; dNTPs (2.5 mM each), $5.0 \mu \mathrm{l}$; $10 \mathrm{~F}$ primer $(100 \mathrm{pmol} / \mu \mathrm{l}), 0.75 \mu \mathrm{l} ; 800 \mathrm{R}$ primer $(100 \mathrm{pmol} / \mu \mathrm{l}), 0.75 \mu \mathrm{l}$; Taq polymerase $(5 \mathrm{U} / \mu \mathrm{l}), 0.25 \mu \mathrm{l}$; sterile bi-distilled water, $34.5 \mu \mathrm{l}$. The running program were: segment 1 (initial denaturation), $94^{\circ} \mathrm{C}, 1 \mathrm{~min}$; segment 2 (amplification cycles), $94^{\circ} \mathrm{C} / 30 \mathrm{sec}, 55^{\circ} \mathrm{C} / 1 \mathrm{~min}, 72^{\circ} \mathrm{C} / 1 \mathrm{~min}$ for 30 cycles; segment 3 (final extension) $72^{\circ} \mathrm{C}, 2 \mathrm{~min}$ followed by $4^{\circ} \mathrm{C}$, 99.9 min. The PCR-product size ranged from 700-800 base pair "bp".

\subsubsection{PCR product confirmation, purification and quantification.}

The PCR product confirmation was done by the gel documentation technique (Sambrook and Russell, 2001). Purification of the product was done using polyethylene glycol (PEG) precipitation technique

(http://www.auburn.edu/ santosr/protocols/PEGTAEProtocol.pdf).

The concentration of the purified DNA was measured using the spectrophotometer (Pharmacia Gene Quant RNA/DNA calculator) at 
$260 \mathrm{~nm}$ wave length, and the concentration was then adjusted to $50 \mathrm{ng} /$ $\mu 1$ using sterile bi-distilled water.

\subsubsection{The DNA sequencing and data analysis}

The purified DNA was loaded into the sequencing plates and dispatched to sequencing company (Takara Biotechnology "Dalian" Co., Ltd.). The obtained data were analyzed using the PhredPhrap genetic software (Fukushi H., Laboratory of Veterinary Microbiology, Department of Veterinary Medicine, Faculty of Applied Biological Sciences, Gifu University, Gifu, Japan). The analyzed sequences were then compared with data in the BLAST database (http://www.ncbi.nlm.nih.gov/blast/). When sequencing data show $\geq$ $99 \%$ identity with a sequence in the database, higher ranked species was judged as identified species.

\section{RESULTS}

Sensory assessment of the examined fessiekh samples revealed that most $(88.23 \%)$ of them were organoleptically accepted, where 5 $(29.41 \%)$ and $10(58.82 \%)$ out of the 17 samples were categorized as of good and medium quality, respectively, while $2(11.77 \%)$ were of bad quality. The 2 bad samples were evaluated highly to extremely rancid (results not shown). The mean values of the sensory assessment for appearance, juiciness, rancidity, flavor and general acceptability of the examined salted-fish samples were shown in Table 1.

The chemical analysis (Table 2) revealed that the mean values for $\mathrm{pH}$ and $\mathrm{NaCl}$ content of the examined samples were $6.63 \pm 0.16$ and $8.09 \pm 0.33$, respectively. The minimum and maximum values were 6.1 and $8.1 ; 6.13$ and 10.11 for $\mathrm{pH}$ and $\mathrm{Nacl}$, respectively.

As for bacteriological analysis, mean values $\left(\log _{10} \mathrm{cfu} / \mathrm{g}\right)$ of 4.66 $\pm 0.53,6.05 \pm 0.25$, and $4.63 \pm 0.2$ were found for total mesophilic aerobes, halophiles, and total anaerobes, respectively. The bacterial counts $\left(\log _{10} \mathrm{cfu} / \mathrm{g}\right)$ ranged from 2.64 to 6.91 for total mesophilic aerobes; from 4.46 to 7.93 for halophiles and from 3.3 to 6.23 for total anaerobes (Table 3). Out of the 17 examined sample, only 10 (58.82\%) show detectable count of mesophilic aerobes $\left(>2 \log _{10} \mathrm{cfu} / \mathrm{g}\right)$, while the other 7 (41.18\%) samples show non detectable count $\left(<2 \log _{10} \mathrm{cfu} / \mathrm{g}\right)$ (results not showen). 
As clarified in Table 4 a total of 96 bacterial strains isolated from the examined salted fish samples was characterized using PCRsequencing technique. Out of the 96 isolated strains, 29 (30.21\%) were from mesophilic aerobes, 31 (32.29\%)) were from halophiles, and 36 (37.5\%) were from anaerobes. The 29 strains of mesophilic aerobes were 18 (62.07\%) strains Staphylococcus equorum srain JH6, 6 (20.69\%) strains Staph. sp. L50, 2 (6.9\%) strains each of Bacillus subtilis subspecies subtilis strain BCRC 10255 and Lactobacillus sp. CWBI/B659/(E912), and 1 (3.45) strain Bacillus subtilis.

As for halophiles, the 31 PCR identified strains included 16 (51.61\%) strains Staphylococcus equorum srain JH6, 10 (32.26\%) strains Staph. sp. L50, and $5(16.13 \%)$ strains Teratogenococcus halophilus. Out of the 36 characterized anaerobic strains, 23 (63.89\%) were Clostridium bifermentans strain IBUN 188, 7 (19.44\%) were Clostridium bifermentans strain IBUN 179, 3 (8.33\%) were Clostridium sp. Zx5, and 1 (2.78\%) was each of Clostridium butyricum strain W4, Clostridium cochlearium, and Clostridium sp. DF2C1 (Table 4) .

Table 1: Sensory assessment of the examined salted-fish samples

\begin{tabular}{|l|l|l|l|l|l|l|}
\hline & Appearance & Juiciness & Saltiness & Rancidity & Flavor & $\begin{array}{c}\text { General } \\
\text { acceptability }\end{array}$ \\
\hline Mean \pm SE & $3.24 \pm 0.14$ & $3.24 \pm 0.14$ & $2.41 \pm 0.12$ & $3.88 \pm 0.27$ & $3.00 \pm 0.21$ & $3.18 \pm 0.15$ \\
\hline
\end{tabular}

Table 2: Chemical analysis values of the examined salted-fish samples

\begin{tabular}{|c|c|c|c|}
\hline Chemical analysis & Mean \pm SE & Minimum & Maximum \\
\hline $\mathrm{pH}$ & $6.63 \pm 0.16$ & 6.1 & 8.1 \\
\hline Salt $(\%)$ & $8.09 \pm 0.33$ & 6.13 & 10.11 \\
\hline
\end{tabular}


Table 3: Bacteriological analysis results $\left(\log _{10} \mathrm{cfu} / \mathrm{g}\right)$ of the examined salted-fish samples

\begin{tabular}{|l|c|c|c|}
\hline \multicolumn{1}{|c|}{ Microorganisms } & Mean \pm SE & Minimum & Maximum \\
\hline $\begin{array}{l}\text { Total Mesophilic Aerobes } \\
(\mathrm{n}=10)^{*}\end{array}$ & $4.66 \pm 0.53$ & 2.64 & 6.91 \\
\hline Halophiles & $6.05 \pm 0.25$ & 4.46 & 7.93 \\
\hline Total Anaerobes & $4.63 \pm 0.2$ & 3.3 & 6.23 \\
\hline
\end{tabular}

Only 10 samples showed detectable count for mesophilic aerobes, the other 7 samples show count $<2 \log _{10} \mathrm{cfu} / \mathrm{g}$

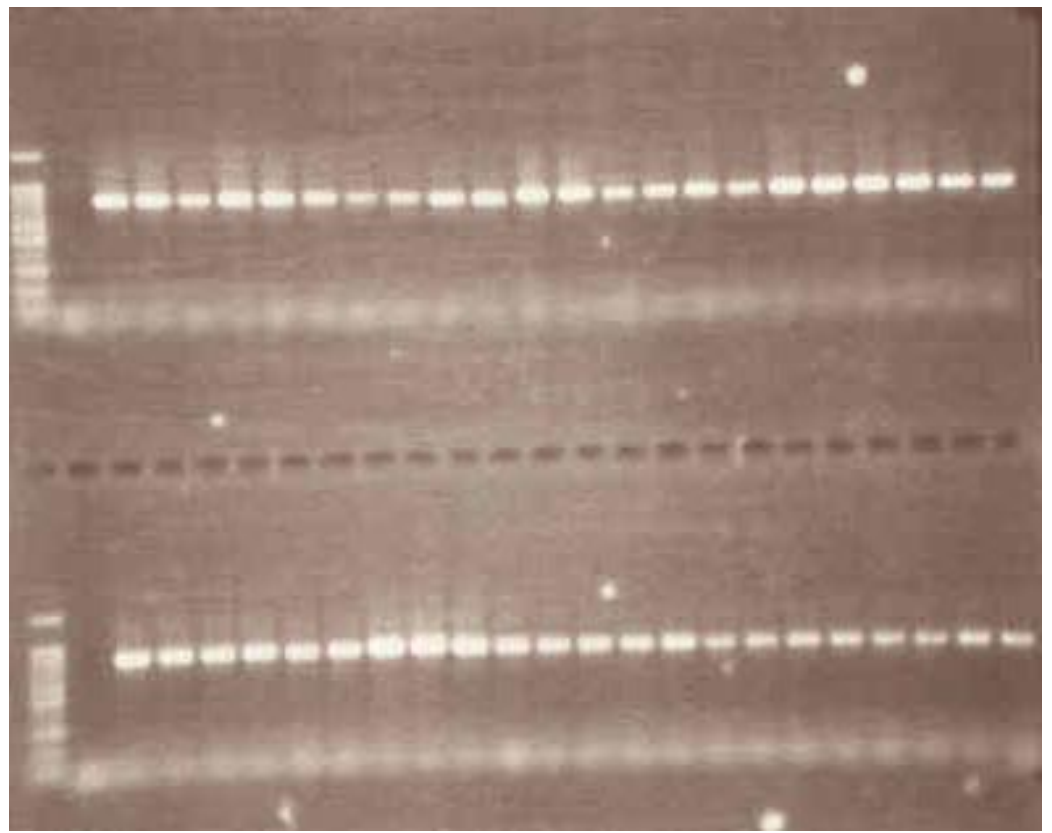

The PCR product for the amplified partial sequence of the 16S rRNA gene of the unknown bacteria.

$\mathrm{M}=$ Marker (100bp)

-ve $=$ Negative control

$1,2,3 \ldots=$ sample numbers 
Table 4: Identified strains isolated from the examined salted-fish samples by PCR-sequencing technique

\begin{tabular}{|l|c|c|c|c|c|c|}
\hline \multirow{2}{*}{\multicolumn{1}{|c|}{ Identified strains }} & \multicolumn{2}{c|}{$\begin{array}{c}\text { Mesophilic } \\
\text { Aerobes }\end{array}$} & \multicolumn{2}{l|}{ Halophiles } & \multicolumn{2}{c|}{ Anaerobes } \\
\cline { 2 - 8 } & No. & $\%$ & No. & $\%$ & No. & $\%$ \\
\hline Bacillus subtilis & 1 & 3.45 & - & - & - & - \\
\hline $\begin{array}{l}\text { Bacillus subtilis subsp. subtilis strain } \\
\text { BCRC10255 }\end{array}$ & 2 & 6.9 & - & - & - & - \\
\hline $\begin{array}{l}\text { Clostridium bifermentans strain } \\
\text { IBUN 179 }\end{array}$ & - & - & - & - & 7 & $\begin{array}{c}19.4 \\
4\end{array}$ \\
\hline $\begin{array}{l}\text { Clostridium bifermentans strain } \\
\text { IBUN 188 }\end{array}$ & - & - & - & - & 23 & 63.8 \\
\hline Clostridium butyricum strain W4 & - & - & - & - & 1 & 2.78 \\
\hline Clostridium cochlearium & - & - & - & - & 1 & 2.78 \\
\hline Clostridium sp.DF2C1 & - & - & - & - & 1 & 2.78 \\
\hline Clostridium sp. Zx5 & - & - & - & - & 3 & 8.33 \\
\hline $\begin{array}{l}\text { Lactobacillus sp. CWBI/B- } \\
\text { 659/(E912) }\end{array}$ & 2 & 6.9 & - & - & - & - \\
\hline Staphylococcus equorum strain JH6 & 18 & 62.07 & 16 & 51.61 & - & - \\
\hline Staphylococcus sp. L50 & 6 & 20.69 & 10 & 32.26 & - & - \\
\hline Teratogenococcus halophilus & - & - & 5 & 16.13 & - & - \\
\hline Total & 29 & 100 & 31 & 100 & 36 & 100 \\
\hline
\end{tabular}

\section{DISCUSSION}

In this study sensory evaluation results of the examined fessiekh samples seemed to be nearly similar to that obtained by El-Morshdy et al. (1981) who found that $10 \%$ of the examined fessiekh samples were unfit for human consumption. On the other hand, it was lower than that obtained by Nayel (2007), who found that $20 \%$ of the examined fessiekh samples showed putrefied odor and rancid taste. 
Concerning the Egyptian standards (EOSQS, 1996) for $\mathrm{pH}$ value of salted fish ( $\mathrm{pH} 6.0-6.5), 29.41 \%$ of the examined samples had $\mathrm{pH}$ values higher than the standards (results not shown). This was lower than that previously reported by El-Sheshnagui (2006), who found that $45 \%$ of the examined fessiekh samples had a $\mathrm{pH}$ exceeded the Egyptian standards. The $\mathrm{pH}$ range and mean values of the examined samples were slightly differed from those previously obtained by El-Sheshnagui (2006). However it was generally higher than those reported by SillaSantos (1996); Hernandez-Herrero (1999b); Majumdar et al. (2006); Patir et al. (2006); Yung-Hsiang et al. (2006); Koffi-Nevry et al. (2011) for a variety of salted fish products. The obtained values were generally lower than those recorded by Steinkraus (1983) and Anihouvi et al. (2006).

Salt is introduced into fish in processing at two levels either for flavoring at about 2 percent as in kippers etc.; or for long term preservation at about $18-20$ percent, as in salt cod (Ranken, 1986). As for the examined fessiekh all the samples had $\mathrm{NaCl}$ content more than 6\% which comply with the established Egyptian standards (EOSQC, 1996) for salted Fish ( $\mathrm{NaCl}$ content not less than 6\%). This was differ from that reported by El-Sheshnagui (2006), who recorded that the salt content of $60 \%$ of the examined fessiekh samples were below the Egyptian standards limit. The obtained results of Nacl mean and range values were higher than those recorded by Sakai et al. (1983); Anihouvi et al. (2006); El-Sheshnagui (2006); Koffi-Nevry et al. (2011). However, they were lower than those recorded by El-Morshdy et al. (1981); Abd El-Rahman (1988); Sanni et al. (2002); Patir et al. (2006); Yung-Hsiang et al. (2006) for a variety of salted fish products.

It is generally accepted that in order to get a picture of the bacterial activity on the fish the easiest and most practical method is to determine the total bacterial count (FAO, 1981). As there is no Egyptian standards for aerobic plate count in salted fish and in comparing the obtained results with Spanish specifications (MSC, 1991) which allow counts up to $5 \log _{10} \mathrm{cfu} / \mathrm{g}$ for mesophilic microorganisms in salted fish products, it is noticed that $23.53 \%$ of the examined fessiekh samples not comply with this specification (results not shown). Nayel (2007) found that $44 \%$ of the examined fessiekh samples had aerobic bacterial count of more than $5 \log _{10} \mathrm{cfu} / \mathrm{g}$, which seemed higher than the current obtained result.

As for recorded mesophilic aerobes count, the mean and range values were nearly similar to that recorded by Vilhemsson et al. (1996) 
for bachalao (salted cod). However, higher values were reported by El-Morshdy et al. (1981); Paludan-Muller et al. (2002); Sanni et al. (2002); Anihouvi et al. (2006) and lower ones were reported by Achinewhu and Oboh (2002); Patir et al. (2006); Yung-Hsiang et al. (2006) for a variety of salted fish products.

Although salt prevents growth of spoilage bacteria, other microorganisms may not be affected by its presence. Microorganisms have been conveniently divided into four groups based on their sensitivity to salt: halotolerant, slight halophiles, moderate halophiles and extreme halophiles. Most halotolerant microorganisms are isolated when foods are tested for slight or moderate halophiles (Baross and Lenovich, 1992). Some halotolerant microorganisms are involved in spoilage of salted foods, whereas others, such as Staph. aureus, are human pathogens (APHA, 1984).

The obtained results of the halophilic bacterial count of the examined fessiekh samples revealed that $88.24 \%$ of them showed count more than $5 \log _{10} \mathrm{cfu} / \mathrm{g}$. Meanwhile, $41.18 \%$ of the samples showed halophiles count more than $6 \log _{10} \mathrm{cfu} / \mathrm{g}$ (results not shown).

The recorded mean and range values for halophiles were higher than those registered by Knockel and Huss (1984); Surono and Hosono (1994); Hernandez-Herrero et al. (1999a); Anihouvi et al. (2006); Patir et al. (2006) for a various types of salted fish products. However the mean value was lower than that reported by Ahmed and El-Kazzaz (2005) for the examined fesseikh samples.

The obtained counts of anaerobic bacteria from the examined fessiekh samples declared that $44.18 \%$ of the samples had anaerobic count exceeded $5 \log _{10} \mathrm{cfu} / \mathrm{g}$, while only $5.88 \%$ of them had count exceeded $6 \log _{10} \mathrm{cfu} / \mathrm{g}$. The result of range and mean values for anaerobes was nearly similar to those recorded by Ahmed (1976) for a variety of salted fish products. However, Anihouvi et al. (2006) recorded a lower range value in lanhouin "a traditionally processed fermented fish in Benin"

In recent years many studies have used culture independent $16 \mathrm{~S}$ rRNA-based PCR techniques to determine the microflora of various traditional salt-fermented fishery products (Ha et al., 2002; PaludanMuller et al., 2002; Abd-Allah, 2008; Tanasupawat et al., 2010; An et al., 2011)

Using PCR-sequencing technique different species of Bacillus, Clostridium, and Staphylococcus could be characterized from the examined fessiekh samples. 
The isolation of diverse microorganisms from fessiekh agreed with the finding of Morshdy et al. (1982); Abd-Allah (2008); who reported the isolation of Bacillus, Citrobacter, Lactobacillus, Micrococcus, Proteus, and Staphylococcus amongst others from fessiekh samples. Bacillus, Clostridium, Enterobacter, Lactobacillus, Micrococcus, Pediococcus, Pseudomonas, Staphylococcus, and Streptococcus had been reported as a microflora amongst others in various salt-fermented fishery products (Ahmed, 1976; Nassar and Ahmed, 1997; Surono and Hosono, 1994; Paludan-Muller et al., 2002; Sanni et al., 2002; Rodrigues et al., 2003; Tanasupawat et al., 2010; An et al., 2011; Koffi-Nevry et al., 2011)

In the current study three strains of Bacillus had been isolated from the examined samples, Bacillus species are spore-forming bacteria known to thrive high concentrations of $\mathrm{NaCl}$. It was suggested that these spore-forming bacilli may play an active role early in the fermentation process (Crisan and Sands, 1975; Sanni et al., 2002). Some strains of Bacillus spp. isolated from Spanish semi-preserved anchovies had been proved to have histidine decarboxylase activity (Rodriguez-Jerez et al., 1994a).

A total of 36 strains of Clostridium had been isolated from the examined samples. Clostridium is strict anaerobic spore-forming bacteria that may be pathogenic or spoilage microorganism. None of the known pathogenic strains of Clostridium (C. botulinum and $C$. perferingens) in salted fish products had been isolated from the current samples. Ahmed (1976); Surono and Hosono (1994); RodriguezJerez et al. (1994b); El-Sebaey et al. (1999) isolated different species of Clostridium from a variety of salted fish products.

Lactic acid bacteria are found as the dominant microorganisms in many fermented fish products (Saisithi et al., 1986; Olympia et al., 1992; Ostergaard et al., 1998; Paludan-Muller et al., 2002; Kopermsub and Yunchalard, 2010). The primary role of Lactobacillus is to ferment the available carbohydrates and thereby cause a decrease in $\mathrm{pH}$. PaludanMuller (2002) reported that the growth of lactic acid bacteria was inhibited in fermented fish with salt concentration more than $10 \% \mathrm{NaCl}$. In the current study, three strains of Lactobacillus (2 strains Lactobacillus sp. CWBI/B-659/(E912) and 1 strain Teratogenococcus halophilus) were isolated from the examined fessiekh samples. Teratogenococcus halophilus, is a halophilic lactic acid bacterium active in the fermentation process of salted fish products (Villar et al., 1985; Nishimura et al., 2009). It was previously isolated from fermented fish 
products with salt concentration higher than $10-15 \%$ such as plaa-ra, nam-budu (fish sauce) and nam-plaa (fish paste) (Tanasupawat and Daengsubha, 1983; Ito et al., 1985).

The isolation of lactic acid bacteria agreed with the findings of Bashir and Agab (1987); Abd El-Rahman et al. (1988); Surono and Hosono (1994); Sanni et al. (2002); Kopermsub and Yunchalard (2010) who reported the isolation of Lactobacillus among others from various salted fish products. Karnop (1988) reported that some Lactobacillus strains isolated from semi-preserved anchovies had histidine decarboxylase activity, as well Bover-Cid and Holzapfel (1999) declared that some Lactobacillus strains had importance as tryramine producers.

Staphylococcal contamination is very common for a wide variety of foods. The sources of contamination may be from skin, mouth or nose of workers handling the food (Tatcher and Clark, 1978). Staphylococci grow well in salted food and in low water activity. They isolated from Thai-fermented fish with salt concentrations above $5 \% \mathrm{NaCl}$ (Tanasupawat et al., 1991, 1992) and from Korean fermented (hydrolysed) fish with salt concentrations ranging from $8 \%$ to $26 \% \mathrm{NaCl}$ (Um and Lee, 1996). Some strains of staphylococci had been previously identified as histamine producers in salted anchovies, beside many other bacterial species (Karnop, 1988; Hernandez-Herrero et al., 1999a). Staphylococci were reported as the dominant isolate from various salted fish products including fessiekh (Sanderson et al., 1988; Abd-Allah, 2008). In the current study, out of the 96 identified bacterial strains, 50 (52.08\%) were Staphylococci (34 strains were Staphylococcus equorum strain JH6 and 16 strains were Staohylococcus sp. L50).

Steinkraus (1983); Bashir and Agab (1987); Nassar and Ahmed (1997); Hernandez-Herrero et al. (1999a); Paludan-Muller et al. (2002); Rodrigues et al. (2003); Ahmed and El-Kazzaz (2005); An et al. (2011) recorded different species of Staphylococci (e.g. S. carmosus, S. chonii, $S$. epidermidis, $S$. equorum, S. saprophyticus, S. simulans) amongst others as a microflora from various salt-fermented fish products. Staph. equorum is coagulase-negative cocci currently isolated from fermented sausage (Blaiotta et al., 2004; Rantsiou et al., 2005), curing brines and raw ham. Staphylococcus equorum subsp. equorum was originally isolated from healthy horses (Schleifer et al., 1984), and later isolates were obtained from the milk of a cow with mastitis and from healthy goats (Meugnier et al., 1996). Another subspecies, Staph. equorum subsp. linens, was isolated from the surface of ripening cheese (Place et al., 2003). Few Staph equorum subsp. equorum strains were found in 
relevant human clinical materials (Marsou et al., 2001; Alcaraz et al., 2003; Novakova et al., 2006). It is belived that Staph equorum may contribute to the development of the meat and cheese products flavor, and it may inhibit Listeri's growth (Place et al., 2003). So, it may be beneficial or might be potential pathogen. To the best of my knowledge this is the first record of Staph. equorum in the Egyptian salted Mugil cephalus fish (fessiekh).

In summary, this study showed that most of the examined fessiekh samples were of medium quality, as well considerable percentage of them had high $\mathrm{pH}$ values $(>6.5)$, which may reflect some forms of spoilage. Salt content of all samples was more than $6 \%$. However many of the samples showed high aerobic, halophilic and anaerobic bacterial count, which indicates unhygienic conditions during processing and marketing. Halophiles was the dominant microflora recorded the highest count and the highest number of isolates. Most of the identified isolates are spoilage microorganisms (Bacillus, Clostridium, and Staphylococcus) that might have impact on product shelf-life. Some of them are proved as histidine decarboxylase producers (Bacillus and Staphlococcus), which might affect product safety. Others are considered beneficial (Lactobacillus and some species of Bacillus and Staphylococcus) which can be used to improve product quality and sensory characteristics. It is expected that controlled material handling and fermentation will lead to better microbial status in the product. However, new regulations are required for salted fish products to establish microbiological performance standards for aerobes, halophiles and anaerobes contaminations. Characterization of bacteria presented in fessiesk using molecular methods identified new species and opened several possibilities for further research in the field of spoilage, safety and also the influence of the microorganisms onto the sensory characteristics of this product.

\section{ACKNOWLEDGEMENT}

The author wishes to thank Prof. Dr. Fukushi, H. (Prof, Vet. Micrbiol. Infec. Dis., Fac. Appl. Biolog. Sci. Gifu Univ. Gifu, Japan) for using the molecular materials in his laboratory and for his help in sequencing data analysis. 


\section{REFERENCES}

Abd-Allah, Sh.M.S. (2008): Egyptian Traditional Salted Fishes: Processing Technology and Quality Control Monitoring. Ph. D. Thesis (Meat Hygiene), Fac. Vet. Med., Assiut University.

Abd El-Rahman, H.; El-Khateib, T. and Refai, R.S. (1988): Microbiological studies on the Egyptian salted fish "Moloha". Assiut Vet. Med. J., 19 (38): 90-97.

Ahmed, H.Y. (1976): Studies on the Sanitary Improvements of Locally Manufactured Salted Fish. Ph D Thesis (Meat Hygiene), Fac. Vet. Med., Assiut University.

Ahmed, A.M. and El-Kazzaz, W.M. (2005): Control of halotolerant bacteria in salted fish (Faseikh) using trisodium phosphate. Pakistan J. Biolog. Sci., 8 (6): 882-887.

An, C.; Takahashi, H.; Kimura, B. and Kuda T. (2011): Comparison of PCR-DGGE and PCR-SSCP analysis for microflora of kaburazushi and daikonzushi, traditional fermented foods made from fish and vegetables. J. Food Tech., 9 (1): 1-8.

Anihouvi, V.B.; Ayernor, G.S.; Hounhouigan, J.D. and Sakyi-Dawson, E. (2006): Quality characteristics of lanhouim, a traditionally processed fermented fish product in the Republic of Benin. African J. Food Agri. Nutrition and Development, 6 (1): 1-15. Online: www.ajfand.net

Achinewhu, S.C. and Oboh, C.A. (2002): Chemical, microbiological and sensory properties of fermented fish products from Sardinella $\mathrm{sp}$. In Nigeria. J. Aquatic Food Product Technol., 11 (2): 53-59.

Alcaraz, L.E.; Satorres, S.E.; Lucero, R.M. and Puig de Centorbi, O.N. (2003): Species identification, slime production and oxacillin susceptibility in coagulase-negative staphylococci isolated from nosocomial specimens. Braz. J. Microbiol., 34: 45-51.

AOAC (1980): Official Methods of Analysis of the Association of Official Analytical Chemists. Horwitz, w. (ed.), AOAC $13^{\text {th }}$ ed., Washington D.C.: Association of Official Analytical Chemists.

APHA (1984): Compendium of Methods for the Microbiological Examination of Foods. Speck, H. L. (ed.), APHA, $2^{\text {nd }}$ ed., Washington D.C.: American Public Health Association.

Baross, J.A. and Lenovich, L.M. (1992): Halophilic and Osmophilic Microorganisms. In compendium of Methods for the Microbiological Examination of Foods. Vanderzant, $C$. and 
Splitstoesser, D. F. (ed.), $3^{\text {rd }}$ ed., p. 199-212. Washington, DC. American Public Health association.

Bashir, El-R. and Agab, M.A. (1987): Traditional salted fish with special reference to fasseikh. Faculty of Agriculture, Food Research Center and Unesco Regional Training Course on Fermented Foods of the Arab World, 1-5 February, Shambat, Khartoum, Sudan. 11p.

Blaiotta, G.; Ercolini, D.; Mauriello, G.; Salzano, G. and Villani, F. (2004): Rapid and reliable identification of Staphylococcus equorum by a species-specific PCR assay targeting the sodA gene. Syst. Appl. Microbiol., 27: 696-702.

Bover-Cid, Sara and Holzapfel, W.H. (1999): Improved screening procedure for biogenic amine production by lactic acid bacteria. Int. J. Food Microbiol., 53: 33-41.

Chamkha, M.; Sayadi, S.; Bru, V. and Godon, J.J. (2008): Microbial diversity in Tunisian olive fermentation brine as evaluated by small subunit rRNA-single strand conformation polymorphism analysis. Int. J. Food Microbiol., 122: 211-215.

Chen, H.C.; Wang, S.Y. and Chen, M.J. (2008): Microbiological study of lactic acid bacteria in kefir grains by culture-dependent and culture independent methods. Food Microbiol., 25: 492-501.

Crisan, E.V. and Sands, A. (1975): Microflora of four fermented fish sauces. Applied Microbiology, 29 (1): 106-108.

El-Morshdy, A.; Zeidan, M.A. and Sedik, M.F.S. (1981): Studies on physical, chemical and bacteriological status of salted fishes in Sharkia province. Assiut Vet. Med. J., 8 (15\&16): 127-134.

El-Sebaey, E.S.; Samaha, I.A.; El-Atabany, A.I. and Morshdy, A.M. (1999): Occurrence of some microorganisms in anchovies and their relation to public health. Zag. Vet. J., 27 (1): 78-84.

El-Sebaiy, Laila, A. and Metwalli, S.M. (1989): Changes in some chemical characteristics and lipid composition of salted fermented bouri fish muscle (Mugil cephalus). Food Chemistry, 31: 41-50.

El-Sheshnagui, Sawsan, M.L. (2006): Sanitary evaluation of some salted fishes in Alexandria. Assiut Vet. Med. J., 52 (110): 96-110.

EOSQC (1996): Egyptian Organization for Standardization and Quality Control. ESS1725, part1, 2 and 3 for salted fish.

FAO (1981): Guidelines for Chilled Fish Storage Experiments. FAO Fisheries Technical Paper No. 210. 
Filsinger, B.E. (1987): Effect of pressure of salting and ripening process of anchovies (Engraulis anchoita). J. Food Sci., 52(4): 919-922.

Filsinger, B.E.; Barassi, C.A.; Lupin, H.M. and Trucco, R.E. (1982): An objective index for the evaluation of the ripening of salted anchovy. J. Food Tech., 17: 193-200.

Ha, Y.M.; Park, Y. and Kim, Y.J. (2002): A taxonomic study of Bacillus sp. isolated from Korean salt-fermented anchovy. Molecular Biology Today, 3(1): 25-29.

Hernandez-Herrero, M.M.; Roig-Sagues, A.X.; Rodriguez, J.J. and Mora-Ventura, M.T. (1999a): Halotolerant and halophilic histamine-forming bacteria isolated during the ripening of salted anchovies (Engraulis encrasicholus). J. Food Prot., 62 (5): 509-514.

Hernandez-Herrero, M.M.; Roig-Sagues, A.X.; Lopez-Sabater, E.I.; Rodriguez, J.J. and Mora-Ventura, M.T. (1999b): Total volatile basic nitrogen and other physicochemical and microbiological characteristics as related to ripening of salted anchovies. J. Food Sci., 64 (2): 344-347.

Ikeme, A.I. (1986): Extending the shelf-life of smoked mackerel. FAO Fisheries Report, Suppl. No 329. p. 144-149.

Ito, H.R.S.; Hadioetomo, S.; Nikkuni, S. and Okada, N. (1985): Studies on lactic acid bacteria in fish sauces (part 2). Identification of salt tolerance and acid producing bacteria from fish sauces. Rep. Natl. Food Res. Inst., 47: 31-40.

JPF "Japanese Pharmacopoeial forum"(2003): Rapid identification of microorganisms based on molecular biological method. JP Forum, 12 (1): 35-37.

Karnop, V.G. (1988): Histamine in salzsardellen. Arch. Lebensmittelhyg., 39: 57-84.

Kemp, M.J. (1973): The processing of anchovies in salt and their quality requirements for Spain. British Standard Institution, Tec. Rep. T 243, pp. 1-10, London.

Kim, T.W.; Lee, J.H.; Kim, S.E.; Park, M.H.; Chang, H.C. and Kim, H.Y. (2009): Analysis of microbial communities in doenjang, a Korean fermented soybean paste, using nested PCR-denaturing gradient gel electrophoresis. Int. J. Food Microbiol., 131: 265-271.

Knochel, Susanne and Huss, H.H. (1984): Ripening and spoilage of sugar salted herring with and without nitrate. 1. Microbiological and related chemical changes. J. Food Technol., 16: 203-213. 
Koffi-Nevry, R.; Ouina, T.S.T.; Koussemon, M. and Brou, K. (2011): Chemical composition and lactic microflora of adjuevan, a traditiona Ivorian fermented fish condiment. Pakistan J. Nutrition 10 (4): 332-337.

Kopermsub, P. and Yunchalard, S. (2010): Identification of lactic acid bacteria associated with the production of plaa-som, a traditional fermented fish product of Thailand. Int. J. Food Microbiol., 138: 200- 204

Lyhs, U.; Hatakka, M.; Maki-Petays, N.; Hyytia, E. and Korkeala, H. (1998): Microbiological quality of Finnish vacuum-packaged fishery products at retail level. Archiv fur Lebensmittelhygiene, 49 (6): 146-150.

Majumdar, R.K.; Basu, S. and Nayak, B.B. (2006): Studies on the biochemical changes during fermentation of salt-fermented Indian shad (Tenualosa ilisha). J. Aquatic Food Product Tech., 15 (1): 53-69.

Marsou, R.; Bes, M.; Brun, Y.; Boudouma, M.; Idrissi, L.; Meugnier, H.; Freney, J. and Etienne, J. (2001): Molecular techniques open up new vistas for typing of coagulase-negative staphylococci. Pathol Biol., 49: 205-215.

Meugnier, H.; Bes, M.; Vernozy-Rozand, C.; Mazuy, C.; Brun, Y.; Freney, J. and Fleurette, J. (1996): Identification and ribotyping of Staphylococcus xylosus and Staphylococcus equorum strains isolated from goat milk and cheese. Int. J. Food Microbiol.., 31: 325-331.

Morshdy, A.E.; Sedik, M.F. and Zeidan, M.A. (1982): Bacteriological evaluation of salted fishes marketed in Sharkia province. Assiut Vet. Med. J., 1982, 9 (17\&18): 104-107.

MSC "Minesrterio de Sanidad y Consumo" (1991): RD1521/1991. Directiva del15 de Agosto 19991, orden del 2 de 1991 por la que se aprueban las normas microbiologicas, los limites de contenido en metales pesados y los metodos analiticos para la determinacion de metales pesados para los productos de la pesca y de la acuicultura. Bol. Of. Estado 195: 27513-27515 (Cited after, Pons-Sanchez-Cascado et al., 2005).

Nassar, A. and Ahmed, Amal (1997): Proteolytic microflora contaminants of Alestes nurse (salted fish). Assuit Vet. Med. J., 37 (74): $33-42$. 
Nayel, M.S.Kh. (2007): Microbiological Status of Some Marketed Canned and Pickeled Fish. MVSc Thesis (Food Control). Fac. Vet. Med., Moshtohor, Benha University.

Nishimura, I.; Igarashi, T.; Enomoto, T.; Dake, Y.; Okuno, Y. and Obata, A. (2009): Clinical efficiency of halophilic lactic acid bacterium Tetragenococcus halophilus Th221 from soy sauce moromi for perennial allergic rhinitis. Allergol. Int., 58 (2): 179-185.

Novakova, D.; Sedlacek, I.; Pantucek, R.; Stetina, V.; Svec, P. and Petras, P. (2006): Staphylococcus equorum and Staphylococcus succinus isolated from human clinical specimens. J. Med. Microbiol., 55: 523-528.

Olympia, O.; Ono, H.; Shinmyo, A. and Takano, M. (1992): Lactic acid bacteria in a fermented fishery product, 'Burong bangus'. J. Ferment. Bioeng., 73: 193-197.

Ostergaard, A.; Ben Embarek, P.K.; Yamprayoon, J.; WedellNeergaard, C.; Huss, H.H. and Gram, L. (1998): Fermentation and spoilage of som-fak, a Thai low-salt fish product. Trop. Sci., 38: 105-112.

Paludan-Muller, Christine; Madsen, M.; Sophanodora, P.; Gram, L. and Moller, P.L. (2002): Fermentation and microflora of plaa-som, a Thai fermented fish product prepared with different salt concentrations. Int. J. Food Microbiol., 73: 61-70.

Patir, B.; Inanli, A.G.; Oksuztepe, G. and Ilhak, O.I. (2006): Microbiological and chemical qualities of salted grey mullet (Chalcalburnus tarichii Pallas, 1811). Int. J. Sci. Technol., 1 (2): 91-98.

Place, R.B.; Hiestand, D.; Gallmann, H.R. and Teuber, M. (2003): Staphylococcus equorum subsp. linens, subsp. nov., a starter culture component for surface ripened semi-hard cheeses. Syst. Appl. Microbiol., 26: 30-37.

Pons-Sanchez-Cascado, Sofia; Veciaana-Nogues, M.T.; Bover-Cid, S.; Marine-Font, A. and Vidal-Carou, M.C. ( 2005): Volatile and biogenic amines, microbiological counts, and bacterial amino acid decarboxylase activity throughout the salt-ripening process of anchovies (Engraulis encrasicholus). J. Food Prot., 68 (8): 1683-1689.

Ranken, M.D. (1986): Food Industries Manual. Hill, L. (ed.), $21^{\text {st }}$ ed. Glasgow and London. 
Rantsiou, K.; Lacumin, L.; Cantoni, C.; Comi, G. and Cocolin, L. (2005): Ecology and characterization by molecular methods of Staphylococcus species isolated from fresh sausage. Int. J. Food Micrbiol. 97: 277-284.

Rodrigues, M.J.; Ho, P.; Lopez-Caballero, M.E.; Vaz-Pires, P. and Nunes, M.L. (2003): Characterization and identification of microflora from soaked cod and respective salted raw materials. Food Microbiology, 20: 471-481.

Rodriguez-Jerez, J.J.; Lopez-Sabater, E.I. and Mora-Ventura, M.T.; Hernandez-Herrero, M. (1994a): Histidine, lysine, and ornithine decaeboxylase bacteria in Spanish salted semi-preserved anchovies. J. Food Prot. 57 (9): 784-787, 791.

Rodriguez-Jerez, J.J.; Lopez-Sabater, E.I.; Roig-Sagues, A.X. and MoraVentura, M.T. (1994b): Histidine, cadaverine and putrescine forming bacteria from ripened semi-preserved anchovies. J. Food Sci., 59 (5): 998-1001.

Saisithi, P.; Yongmanitchai, P.; Chimanage, P.; Wongkhalaung, C.; Boonyaratanakornit, $M$. and Maleehuan, S. (1986): Improvement of a Thai traditional fermented fish product: Somfug. The Food and Agriculture Organization, United Nations, Rome.

Sakai, H.; Caldo, G.A. and Kozaki, M. (1983): The fermented fish food Burongisda in the Philippines. J. Agri. Sci. (Tokyo), 28 (2): 138-144.

Sambrook, J. and Russell, D.W. (2001): Molecular Coloning, A Laboratory Manual. Sambrook, J. and Russell, D. W. (ed), $3^{\text {rd }}$ ed., Volume 3. Cold Spring Harbor, New York.

Sanderson, K.; McMeekin, T.A.; Indriati, N.; Anggawati, A.M. and Sudrajat, Y. (1988): Taxonomy of halophilic and halotolerant bacteria from Indonesian fish and brine samples. ASEAN Food J., 4: 31-37.

Sanni, A.I.; Asiedu, M. and Ayernor, G.S. (2002): Microflora and chemical composition of monomi, a Ghanaian fermented fish condiment. J. Food Comp. Analy., 15: 577-583.

Schleifer, K.H.; Kilpper-Balz, $R$. and Devriese, L.A. (1984): Staphylococcus arlettae sp. nov., S. equorum sp. nov. and $S$. kloosii sp.nov. Three new coagulase-negative, novobiocinresistant species from animal. Syst. Appl. Microbiol., 5: 501-509. 
Silla Santos, M.H. (1996): Biogenic amines: their importance in foods. Int. J. Food Microbiol., 29: 213-231.

Singh, S.; Goswami, P.; Singh, R. and Heller, K.J. (2009): Application of molecular identification tools for lactobacillus, with a focus on discrimination between closely related species. LWT-Food Sci. Technol., 42: 448-457.

Steinkraus, K.H. (1983): Handbook of Indigenous Fermented Foods. Marcel Dekker, Inc., New York. P. 494-498.

Surono, U.S. and Hosono A. (1994): Chemical and aerobic bacterial composition of "Terasi", a traditional fermented product from Indonesia. J. Food Hyg. Sco. Japan, 35 (3): 299-304.

Tanasupawat, S.; Chamroensaksri, N.; Kudo, T. and Itoh, T. (2010): Identification of moderately halophilic bacteria from Thai fermented fish (pla-ra) and proposal of Virgibacillus siamensis sp. nov.. J. Gen. Appl. Microbiol., 56: 396-379.

Tanasupawat, S. and Daengsubha, W. (1983): Pediococcus species and related bacteria found in fermented foods and related materials in Thailand. J. Gen. Appl. Microbiol., 29: 487-506.

Tanasupawat, S.; hashimoto, Y.; Ezaki, T.; Kozaki, M. and Komagata, K. (1991): Identification of Staphylococcus carnosus strains from fermented fish and soy sauce mash. J. Gen. Appl. Microbiol., 37: $479-494$.

Tanasupawat, S.; hashimoto, Y.; Ezaki, T.; Kozaki, M. and Komagata, K. (1992): Staphylococcus piscifermentans sp. nov., from fermented fish in Thailand. Int. J. Syst. Bacteriol., 42: 577-581.

Tarr, H.L.A. (1969): Nutritional value of fish muscle and problems associated with its preservation. J. Canadian. Inst. Food Tech., 2(1): 42-45.

Tatcher, F.S. and Clark, D.S. (1978): Microorganisms in Foods. Academic Press, N.Y.

Um, M.-N. and Lee, C.-H. (1996): Isolation and identification of Staphylococcus sp. from Korean fermented fish products. J. Microbiol. Biotechnol., 6: 340-346.

Van Klaveren, F.W. and Legendre, R. (1965): Salted cod. In: Fish as Food. Borgestrom, G. (ed.). Academic Press, London, pp 133-163.

Vilhelmsson, O.; Hafsteinsson, H. and Kristjansson, J.K. (1996): Study of microbiological parameters associated to the ripening of anchovies (Engraulis encrasicholus). Alimentaria, 275: 121-126. 
Villar, M.; DE Ruiz Holgado, A.P.; Sanchez, J.J.; Trucco, R.E. and Oliver, G. (1985): Isolation and characterization of Pediococcus halophilus from salted anchovies (Engraulis anchoita). Appl. Environ. Microbiol., 49 (3): 664-666.

Wheaton, F.W. and Lawson, T.B. (1985): Processing Aquatic Food Products. John Wiley and Sons, New York, USA.

Yang, C.; Jhavari, S.N. and Constantinides, S.M. (1981): Preservation of grey fish (Squalus acanthias) by salting. J. Food Sci., 46: 1646-1649.

Yung-Hsiang, T.; Chueh-Yueh, L.; Liang-Tan, C.; Tsong-Ming, L.; Cheng-I, W. and Deng-Fwu, H. (2006): Histamine contents of fermented fish products in Taiwan and isolation of histamineforming bacteria. Food Chem., 98: 64-70. 